\title{
Bcl-2 down modulation in WEHI-3B/CTRES cells resistant to Cholera Toxin (CT)-induced apoptosis
}

Augusto Pessina ${ }^{1}$, Cristina Croera ${ }^{2}$, Nicoletta Savalli ${ }^{3}$, Arianna Bonomi ${ }^{1}$, Loredana Cavicchini ${ }^{1}$, Elisa Turlizzi ${ }^{1}$, Fabiana Guizzardi ${ }^{1}$, Lucia Guido ${ }^{1}$, Laura Daprai ${ }^{1}$, Maria Grazia Neri ${ }^{1}$

${ }^{1}$ Institute of Microbiology, University of Milan, Via Pascal 36, 20133 Milan, Italy; ${ }^{2}$ ECVAM, Institute for Health and Consumer Protection, European Commission Joint Research Centre, Ispra 21020, Italy; ${ }^{3}$ UCLA, Department of Anesthesiology, Los Angeles, CA 90095, USA

The very different effects of Cholera Toxin (CT) on cell growth and proliferation may depend on the type of ganglioside receptors in cell membranes and different signal transduction mechanisms triggered, but other functions related to the drug resistance mechanisms can not be excluded. The effect of CT treatment on the "in vitro" clonogenicity, the Population Doubling Time (PDT), apoptosis, PKA activation and Bax and Bcl-2 expression was evaluated in WEHI-3B cell line and its CT-resistant subclone (WEHI-3B/CTRES). In WEHI-3B parental cells the dramatic accumulation of cAMP induced by CT correlated well with PKA activation, increased PDT value, inhibition of clonogenicity and apoptosis. H-89 treatment inhibited PKA activation by CT but did not protect the cells from apoptosis and growth inhibition. In WEHI-3B/CTRES no significant CT-dependent accumulation of cAMP occurred with any increase of PKA activity and PDT. In CT resistant cells (WEHI-3B/CTRES), Bcl-2 expression was down regulated by both CT or drug treatment (eg., ciprofloxacin, CPX) although these cells were protected from CT-dependent apoptosis but not from drug-induced apoptosis. Differently from other cell models described, down regulation of Bcl-2 is proved to be independent on cAMP accumulation and PKA activation. Our observations support the implication of cAMP dependent kinase (PKA) in the inhibition of WEHI-3B cells growth and suggest that, in WEHI-3B/CTRES, Bcl-2 expression could be modulated by $\mathrm{CT}$ in the absence of cAMP accumulation. Also in consideration of many contradictory data reported in literature, our cell models (of one sensitive parental cell strain and two clones with different uncrossed specific resistance to CT and CPX) provides a new and interesting tool for better investigating the relationship between the CT signal transduction mechanisms and Bcl-2 expression and function.

Cell Research (2006) 16:306-312. doi:10.1038/sj.cr.7310038; published online 16 March 2006

Keywords: cholera toxin, Bcl-2, PKA, apoptosis, ciprofloxacin, resistance

\section{Introduction}

The ability of Cholera Toxin (CT) to inhibit cell growth and proliferation is related to mechanisms that involving different transduction signals, most of which have ganglioside GM1a as functional receptor [1,2], although other classes of gangliosides may act as functional receptors in

Correspondence: Augusto Pessina

Tel: +392 50315072; Fax: +392 50315068;

E-mail: augusto.pessina@unimi.it

Received 27 June 2005; revised 13 October 2005; accepted 25 October 2005, published online 16 March 2006 cellular transducing inhibitory signals [3-5]. As reported by many authors [6-8], in some cells, the inhibition by CT seems to be mediated by cAMP accumulation whereas in others it is related to cAMP-independent mechanisms and involves $\mathrm{Ca}^{++}$efflux inhibition [9-13]. As reported in previous studies [14-16], murine myelomonocytic leukemia cells (WEHI-3B) are very sensitive to CT that caused a dramatic inhibition of cell proliferation. These studies have shown that CT binds a specific Gal-GalNac-GM1b ganglioside receptor present in WEHI-3B cells and that the inhibition of cell proliferation correlates well with the intracellular accumulation of cAMP. The central role of cAMP in WEHI$3 \mathrm{~B}$ cells growth inhibition by $\mathrm{CT}$ has been also clarified and 
confirmed by studying a WEHI-3B subclone expressing a phenotypic resistance to $\mathrm{CT}$ and absence of Gal-GalNacGM1b ganglioside [17].

In this study we investigated if the inhibition of cell proliferation by $\mathrm{CT}$ was correlated to an increase of the Population Doubling Time (PDT) and/or to an increase of apoptosis by checking also the possible role of cAMPdependent protein kinase (PKA) activation and the expression of $\mathrm{Bax}$ and $\mathrm{Bcl}-2$ genes. Our results suggest that PKA activation, caused by cAMP accumulation produced by $\mathrm{CT}$, may have a role in the inhibition of WEHI-3B cell proliferation. Furthermore, we compared WEHI-3B/CTRES cells with a subclone of the same parental cells but resistant to Ciprofloxacin (WEHI-3B/CPXRES) and found that expression of anti-apoptotic gene Bcl-2 could be involved with the mechanism of the specific resistance to CT-induced apoptosis observed in WEHI-3B/CTRES.

\section{Material and Methods}

\section{Reagents and antibodies}

CT was purchased from Sigma Chemical Co. (USA). Starting solution of CT was prepared in bidistilled water at a concentration of $10^{-5} \mathrm{M}$. Endotoxin contamination of the reagents has been excluded by E-Toxate test (Sigma, USA). IBMX (3-isobutyl-1-methylxanthine) was purchased from Sigma (USA) and starting solution was prepared in DMSO at a concentration of $1 \mathrm{M}$. The PKA inhibitor H-89 (N-[2-((3-4-bromophenyl)-2-propenyl)-amino)-ethyl]-5-isoquinolinesulfonamide di- $\mathrm{HCl}$ ) was purchased from Alexis Biochemicals (USA), and prepared in DMSO at a concentration of $10^{-2} \mathrm{M}$. Ciprofloxacin (CPX) was purchased from Bayer (Wuppertal, Germany) and prepared at $10000 \mu \mathrm{g} / \mathrm{ml}$ in sterile distilled water.

Working dilutions of the reagents for each specific experiment were performed in the medium used for cell cultures.

The following primary antibodies were used: rabbit IgG polyclonal antibody anti-mouse Bax (Santa Cruz Biotechnology, USA) $(200 \mu \mathrm{g} / \mathrm{ml})$; rabbit IgG polyclonal antibody anti-human Bcl-2 (Santa Cruz Biotechnology, USA) $(200 \mu \mathrm{g} / \mathrm{ml})$. As secondary antibody we used goat anti-rabbit IgG HRP-conjugated antibody (Santa Cruz Biotechnology, USA) $(400 \mu \mathrm{g} / \mathrm{ml})$.

\section{Cell lines}

The two subclones of WEHI-3B cells resistant respectively to cholera toxin or ciprofloxacin were obtained from the same parental strain WEHI-3B $\left(\mathrm{D}^{+}\right)$[18]. As previously described [17] WEHI3B/CTRES were obtained by treating cells with $10 \mathrm{nM}$ CT in agar cultures and then selecting a resistant clone in liquid culture, whereas WEHI-3B/CPXRES line was selected by treating cells with increasing concentration of ciprofloxacin [19].

Both WEHI-3B and the resistant subclones were continuously maintained in culture in McCoy's medium (Euroclone, UK) $+5 \%$ FCS (Fetal Calf Serum) by weekly subcultures in $25 \mathrm{~cm}^{2}$ plastic flasks (Greiner Bio-One, Germany). The Resistant Index (RI) of subclones was periodically verified by a clonogenic assay [14] or by a MTT test [20] and expressed as ratio between the $\mathrm{IC}_{50}$ values (CT or CPX concentration producing $50 \%$ reduction of proliferation or clonogenicity). RI determined in proliferation test were $>46000$ for
WEHI-3B/CTRES and $16.9 \pm 1.4$ for WEHI-3B/CPXRES.

\section{Treatment of cells}

The cells, washed twice in PBS were resuspended in McCoy's medium supplemented with $2 \% \mathrm{FCS}+1 \mathrm{mM}$ IBMX at a density of $2 \times 10^{6}$ cells $/ \mathrm{ml}$ for apoptosis test and of $4 \times 10^{5}$ cells $/ \mathrm{ml}$ for PDT clonogenic test and PKA activation test.

For testing apoptosis, $1 \mathrm{ml}$ of each cell line suspension was distributed in a 24 well-plate, and according to the experimental design, CT was added at a final concentration of $10 \mathrm{nM}$, both in the presence and in the absence of $10 \mu \mathrm{M} \mathrm{H}-89$ (added 60 min before). Control cultures did not receive $\mathrm{CT}$ or received $10 \mu \mathrm{M} \mathrm{H}-89$ alone. After a treatment of $1 \mathrm{~h}$ at $37{ }^{\circ} \mathrm{C}$ in air $+5 \% \mathrm{CO}_{2}$ the cells were washed twice at $400 \times \mathrm{g}, 10 \mathrm{~min}$ and used for DNA fragmentation test as described below. For PDT test, cells were distributed in 25 $\mathrm{cm}^{2}$ Flasks ( $4 \mathrm{ml} /$ flask) and after $70 \mathrm{~h}$ their growth was estimated by counting the number of cells in a haemocytometric chamber. The main growth parameters (including PDT value) were evaluated as suggested by McAteer et al. [21]. To control cell apoptosis and Bax, Bcl-2 expression, two further experimental conditions were set by culturing cells for $24 \mathrm{~h}$ in the presence of topoisomerases inhibitor $(\mathrm{CPX})$ at $200 \mu \mathrm{g} / \mathrm{ml}$ or in serum deprived medium. The biological activity of CT was verified and confirmed on Y1 cells according to the method suggested by Donta [22].

\section{Clonogenic and proliferation assays}

In vitro clonogenic capacity of WEHI-3B and resistant subclones was evaluated by a soft agar culture assay [14] as follows. At the end of the CT treatment above described, the cells were washed twice in PBS at $400 \times \mathrm{g}, 10 \mathrm{~min}$ and then 300 cells, resuspended in a mixture of $0.9 \mathrm{ml} \mathrm{McCoy's} \mathrm{medium} \mathrm{+} \mathrm{agar} \mathrm{(0.3 \% ),} \mathrm{were} \mathrm{plated} \mathrm{in} 35 \mathrm{~mm}$ Petri dishes (NUNC, Denmark). After $7 \mathrm{~d}$ of incubation at $37{ }^{\circ} \mathrm{C}$ in air + $5 \% \mathrm{CO}_{2}$ the number of colonies was evaluated by the microscope and $\%$ of clonogenicity was calculated on control cultures. For proliferation assay $10^{3}$ cells/well were cultured in 96 well microtiter plates in the presence of CT (serial 1:5 dilutions from $80 \mathrm{nM}$ to $0.008 \mathrm{nM}$ ) or CPX (serial 1:2 dilutions from $1000 \mu \mathrm{g} / \mathrm{ml}$ to $7.8 \mu \mathrm{g} / \mathrm{ml}$ ). After seven days, at $37{ }^{\circ} \mathrm{C}$ in air $+5 \% \mathrm{CO}_{2}$ the cells viability was quantified by MTT (3-(4,5-dimethyl-2-thiazolyl)-2,5-diphenyl-2-H-tetrazolium bromide) as previously described [20,23].

\section{Apoptosis detection}

Apoptosis in WEHI-3B and WEHI-3B/CTRES was verified by checking the DNA fragmentation according to the method suggested by Hermann et al. [24]. Briefly, after treatment, the cells were washed with phosphate buffer saline (PBS), pelletted by centrifugation at $1600 \times \mathrm{g}$ for $5 \mathrm{~min}$ and lysed by $10 \mathrm{~s}$ treatment with $50 \mu \mathrm{l}$ of Apoptotic Buffer (1\% NP-40 in $20 \mathrm{mM} \mathrm{Na-EDTA,} 50 \mathrm{mM}$ Tris-HCL, $\mathrm{pH}$ 8.0). After centrifugation at $1600 \times \mathrm{g}$ for $5 \mathrm{~min}$ the supernatant was collected and the extraction was repeated on the pellet with the same amount of Apoptotic Buffer. The supernatants were brought to $1 \%$ SDS and treated for 90 min with Rnase-A (final concentration $2 \mu \mathrm{g} / \mathrm{ml}$ ) at $56{ }^{\circ} \mathrm{C}$ followed by digestion with proteinase $\mathrm{K}$ (final concentration $2.5 \mu \mathrm{g} / \mathrm{ml}$ ) for $90 \mathrm{~min}$ at $37^{\circ} \mathrm{C}$. After addition of 0.5 volume of $10 \mathrm{M}$ ammonium acetate, the DNA was precipitated with 2.5 volumes of ethanol absolute at $-20^{\circ} \mathrm{C}$ for at least $2 \mathrm{~h}$. After centrifugation for $10 \mathrm{~min}$ at $14000 \times \mathrm{g}$, the pellet was suspended in 70 $\%$ ethanol and further centrifuged for $10 \mathrm{~min}$ at $14000 \times \mathrm{g}$. The final pellet was dissolved in sterile TE $(10 \mathrm{mM}$ Tris and $1 \mathrm{mM}$ EDTA, $\mathrm{pH}$ 
8.5 ) and separated by electrophoresis on $1 \%$ agarose gel.

\section{PKA activation}

According to the experimental design, after each treatment, the cells were washed in PBS, pelletted at $600 \times \mathrm{g}$ for $10 \mathrm{~min}$ and lysed in $50 \mathrm{mM}$ Tris- $\mathrm{HCl}, 5 \mathrm{mM}$ EDTA, $10 \mathrm{mM}$ 2-ME, $1 \%$ Triton-X 100, $1 \mathrm{mM}$ PMSF (Phenyl-methanesulfonyl fluoride) for $10 \mathrm{~min}$ in ice. The samples were centrifuged at $14000 \times \mathrm{g}$ for $15 \mathrm{~min}$ and then the supernatants, collected for protein determination, were used for PKA assay PepTag ${ }^{\circledR}$ Non-Radioactive Assay (Promega, USA) performed in the absence of exogenous cAMP. The assay utilizes as substrate the fluorescinated peptide LRRASLG (Kemptide) that is specifically phosphorylated by PKA and easily separated by the non-phosphorylated form in $0.8 \%$ agarose gel electrophoresis at $100 \mathrm{~V}$ for $15 \mathrm{~min}$. The gels were photographed by a transilluminator and the spots were red by densitometry in order to have a semiquantitative determination of PKA according to the Scion Image Release programme (Scion Corporation, Maryland, USA). As described in the detailed procedure of the kit, the activity of PKA was normalized against a negative control containing PepTag ${ }^{\circledR}$ peptide without kinase used to determine the exact molar absorptivity of the dye in the system.

\section{Western Blotting}

After each treatment, the cells were checked for their viability and cellular extracts for Western Blotting were prepared as follows. After centrifugation at $1000 \times \mathrm{g}$ for $10 \mathrm{~min}$, the cells were suspended in PBS and then pelletted at $1000 \times \mathrm{g}$ for $10 \mathrm{~min}$. The pellets were resuspended in Lysis Buffer ( $150 \mathrm{mM} \mathrm{NaCl}, 0.5 \mathrm{mM}$ EDTA, $0.5 \mathrm{mM}$ $\mathrm{MgCl}_{2}, 10 \mathrm{mM}$ Tris, $1 \%$ TritonX-100, 1 mM PMSF, 1 mM DTT, 10 $\mu \mathrm{g} / \mathrm{ml}$ aprotinin, $10 \mu \mathrm{g} / \mathrm{ml}$ leupeptin, $1 \mu \mathrm{g} / \mathrm{ml}$ pepstatin, $10 \mu \mathrm{g} / \mathrm{ml}$ trypsin inhibitor), vortexed, incubated on ice for $30 \mathrm{~min}$ and after centrifugation at $14000 \times \mathrm{g}$ for $15 \mathrm{~min}$, surnatants containing all cell proteins were collected and stored at $-80^{\circ} \mathrm{C}$. Protein concentration of lysates was determined by Bradford assay [25].

Cellular extracts were denatured at $95^{\circ} \mathrm{C}$ for $5 \mathrm{~min}$ and then subjected to electrophoresis in $12.5 \%$ SDS polyacrylamide gel by the method of Laemmli [26]. Proteins on the gel were transferred through a semi-dry blotter system (Milliblot-Graphite Electroblotter System, Millipore, USA) to PVDF membranes (Immobilon-P, Millipore,

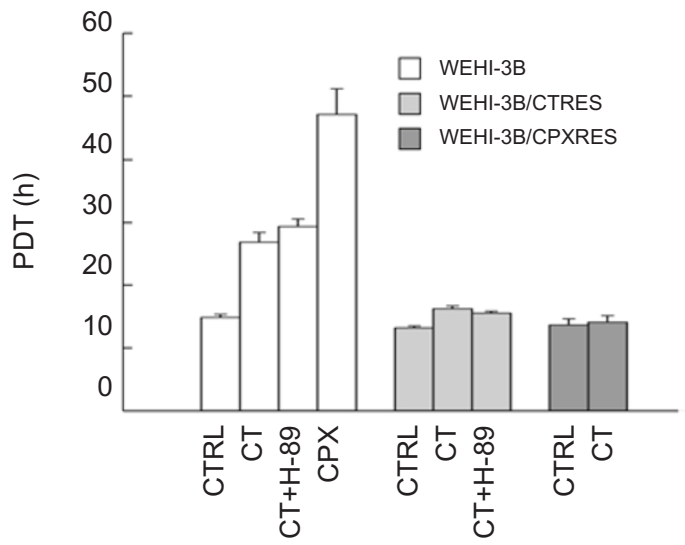

Figure 1 Effect of CT and CPX on cell PDT. Each column expresses the mean $\pm \mathrm{SE}$ of at least three independent experiments.
USA) as essentially described by Towbin et al. [27]. After saturation in 1\% BSA (AppliChem, Ottoweg, Darmstadt, DE) in TBST (Tris Buffer Solution $+0.2 \%$ Tween 20 ) for $1 \mathrm{~h}$ at room temperature, the membrane was incubated over-night at $4{ }^{\circ} \mathrm{C}$ with the primary antibody diluted 1:200 in 1\% BSA in TBST. After three further washing with TBST, the blot was incubated for $45 \mathrm{~min}$ at room temperature with secondary antibody diluted 1:500 in 1\% BSA-TBST. After three washing with TBST and two in TBS, the membrane was developed by an Enhanced Chemiluminescence Technique (SuperSignal West Pico Chemiluminescent Substrate, Pierce Biotechnology, IL, USA) using Hyperfilm ECL (Amersham, Buckinghamshire, UK).

\section{Statistical analysis}

Differences between the means were evaluated according to the Student's " $t$ " test. $P$ values exceeding 0.05 were not considered significant. The linearity of response and the correlation studies have been performed by Instat programme (Graphpad, USA).

\section{Results}

\section{Effect of CT on the PDT and clonogenicity}

As shown in Figure 1 the basal PDT values of the three lines $(14.85 \mathrm{~h} \pm 0.51 \mathrm{~h}$ for WEHI-3B, $13.20 \pm 0.29$ for WEHI-3B/CTRES and $13.64 \pm 1.04$ for WEHI-3B/ CPXRES) do not differ significantly $(P>0.05)$.

The treatment with $10 \mathrm{nM}$ CT produces a dramatic increase of PDT in WEHI-3B cells $(26.86 \mathrm{~h} \pm 1.57 \mathrm{~h})$ whereas it does not affect significantly PDT of the resistant subclone $(16.25 \mathrm{~h} \pm 0.47 \mathrm{~h})$. The presence of $\mathrm{H}-89$ does not produce any modulation of the effect produced by CT.

Also the treatment with CPX $(200 \mu \mathrm{g} / \mathrm{ml})$ produces a dramatic increase of PDT in the WEHI-3B parental cells $(47.16 \mathrm{~h} \pm 4.1 \mathrm{~h})$ whereas no modulation of PDT value was observed in WEHI-3B/CPXRES $(14.11 \mathrm{~h} \pm 1.06 \mathrm{~h})$. Both WEHI-3B/CPXRES treated with CT and WEHI3B/CTRES treated with CPX show a dramatic increase of PDT values (data not reported), supporting the absence of a cross-resistance between the two subclones.

As shown in the histogram of Figure 2, WEHI-3B cells are very sensitive to the anticlonogenic effect of CT (10 $\mathrm{nM}$ gives a $75 \%$ decrease) whereas the resistant subclone WEHI-3B/CTRES was absolutely refractory to the treatment. The presence of $\mathrm{H}-89$ does not affect the basal clonogenicity of the cell lines, produces an increase of the inhibitory effect of CT to WEHI-3B cells but does not modulate the $\mathrm{CT}$ toxicity to the resistant clone.

\section{Effect of CT on PKA activity}

PKA activity was evaluated as accumulation of phosphorylated substrate (kemptide) by PKA assay performed in the absence of exogenous cAMP and analyzed in agarose gel electrophoresis, as reported in Figure 3. Figure $3 \mathrm{~A}$ shows the agarose gel of one experiment whereas the histogram of Figure $3 \mathrm{~B}$ reports the results (mean $\pm \mathrm{SE}$ ) 


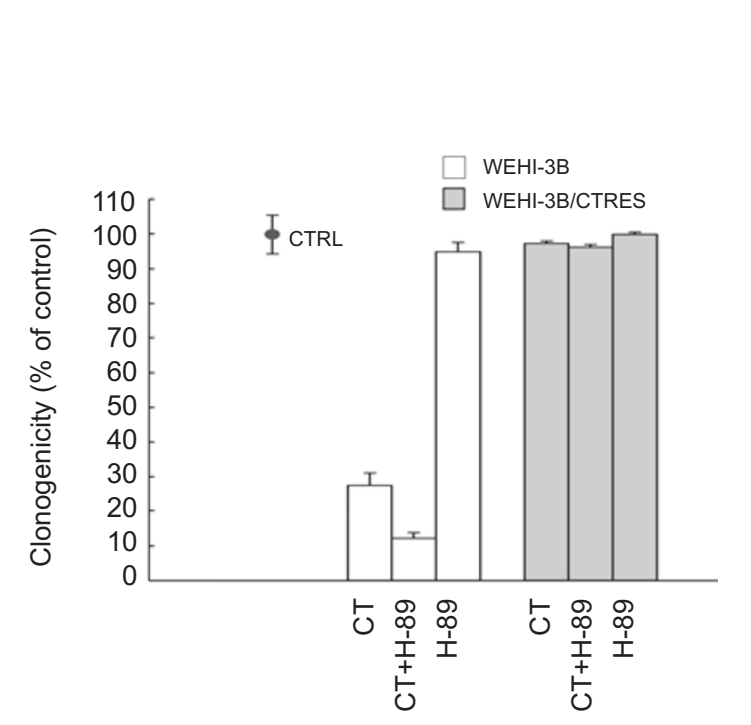

Figure 2 Effect of CT on cell clonogenicity. Each column expresses the mean $\pm \mathrm{SE}$ of at least three independent experiments. $\mathrm{CTRL}=$ Control culture which did not receive treatment and considered as $100 \%$ of cell clonogenicity (absolute number of colony: WEHI-3B $=190 \pm 18$; WEHI-3B/CTRES=175 \pm 20 ).

A

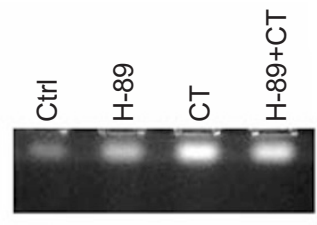

WEHI-3B/CTRES

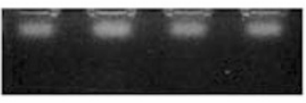

B

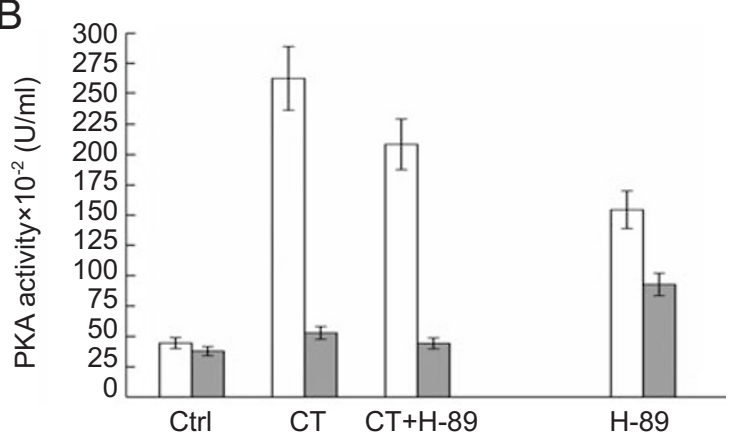

Figure 3 Effect of CT on PKA activation in WEHI-3B and WEHI$3 \mathrm{~B} / \mathrm{CT}$ cell lines. (A) is reported an example of the PKA activation observed in WEHI-3B and WEHI-3B/CT performed by PepTag ${ }^{\circledR}$ assay. The photograph of agarose gel shows the spots corresponding to the kemptide phosphorylated by PKA in the absence of exogenous cAMP. (B) are reported the mean \pm SE of the PKA activity determined in WEHI-3B and WEHI-3B/CTRES (three experiments). The PKA activity is quantified and expressed as $\mathrm{U} / \mathrm{ml}$ (1 U corresponding to the quantity of nanomoles of kemptide phosphorylated by the enzyme in $30 \mathrm{~min}$ ) (See materials and methods).
WEHI-3B

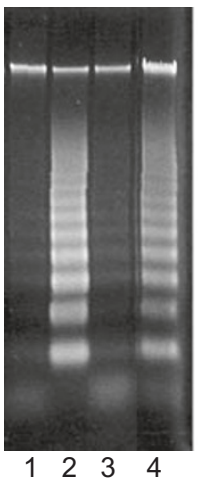

WEHI-3B/CTRES

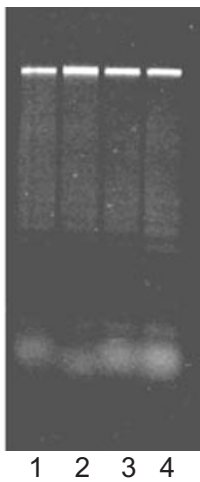

Figure 4 Induction of apoptosis by CT treatment in WEHI-3B ( white columns) and WEHI-3B/ CTRES (grey columns) cell lines. The photographs report the agarose gel runs of DNA extracted from the cells after $24 \mathrm{~h}$ of culture in the different experimental conditions (see Materials and Methods). Lane 1: Untreated cells (controls). Lane 2: Cells treated in the presence of CT, $10 \mathrm{nM}$. Lane 3: Cells treated in the presence of $\mathrm{H}-89,10 \mu \mathrm{M}$. Lane 4: Cells treated in the presence of CT, $10 \mathrm{nM}+\mathrm{H}-89,10 \mu \mathrm{M}$.

of three different experiments quantitatively expressed as Units/ml of PKA.

After CT treatment, a significant $(P<0.001)$ increase of PKA activity in sensitive WEHI-3B cells was observed and the presence of $\mathrm{H}-89$ shows a poor capacity $(P>0.05)$ to counteract this activation. No significant increase $(P>$ 0.2 ) of PKA activity is observed following CT treatment in resistant WEHI-3B cells. Surprisingly, a significant $(P<$ $0.05)$ increase of PKA basal activity was observed in both lines after $\mathrm{H}-89$ treatment.

\section{Induction of apoptosis}

As shown in the agarose gel photographs (Figure 4), untreated cells and the cells treated with $10 \mu \mathrm{M} \mathrm{H}-89$ did not show an appreciable fragmentation of DNA (lane 1 and lane 3). The treatment with $1 \mathrm{nM} \mathrm{CT}$ produced a dramatic increase of DNA fragmentation in WEHI-3B sensitive cells whereas no fragmentation was induced in WEHI-3B/ CTRES (lane 2). The presence of $10 \mu \mathrm{M} \mathrm{H}-89$, during CT treatment, does not modulate the quantity of fragmented DNA observed in both cell lines (lane 4).

A similar experiment, to verify the cross-resistance between the two subclones, is reported in Figure 5. A dramatic increase of DNA fragmentation is observed in the parental cell line treated with both CT and CPX. No DNA fragmentation is seen in WEHI-3B/CTRES treated with CT, whereas high fragmentation is observed after the CPX treatment. The WEHI-3B/CPXRES cells, on the contrary, are sensitive only to CT treatment and do not show DNA fragmentation 

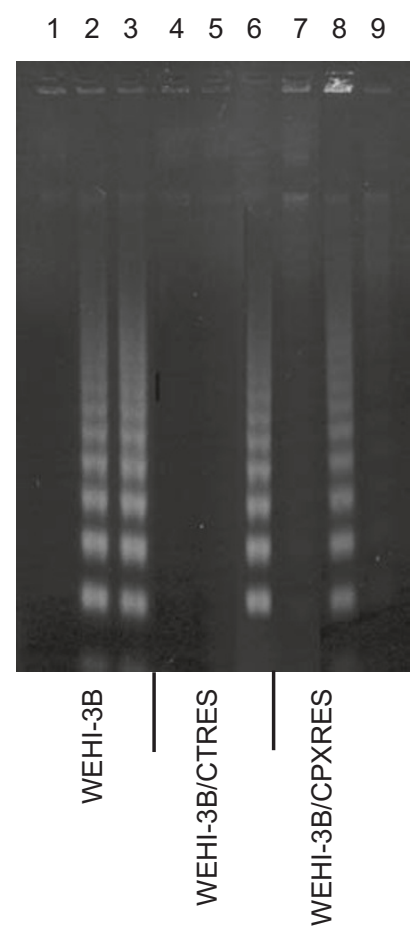

Figure 5 Induction of apoptosis by treatment with cholera toxin and CPX (agarose gel runs of DNA). Lines 1-4-7: Untreated cells (controls). Lines 2-5-8: Cells treated with CT 10 nM. Lines 3-6-9: Cells treated with CPX $200 \mu \mathrm{g} / \mathrm{ml}$.

following CPX treatment. High levels of fragmentation are observed in all the cell lines following a $24 \mathrm{~h}$ growth in serum-deprived medium (data not shown).

\section{Bax and Bcl-2 expression}

The run reported in Figure 6 is referred to one experiment whereas the $\mathrm{Bcl}-2$ /Bax ratio is referred as mean calculated on two different experiments. As shown, Bax and Bcl-2 proteins are expressed both in WEHI-3B (Bcl-2/Bax ratio of 0.52 ) and in the two resistant subclones WEHI-3B/CTRES and WEHI-3B/CPXRES where Bcl-2 is moderately overexpressed (ratios of 0.75 and 0.77 respectively).

In WEHI-3B cells, Bax and Bcl- 2 are not modulated by the treatment with CT (ratio of 0.56) whereas Bcl-2 is strongly up regulated by CPX (to a ratio of 0.91 ) although both the treatment induces cell apoptosis.

In WEHI-3B/CTRES no significant modulation of Bax is produced, $\mathrm{Bcl}-2$ expression is down-modulated both by treatment with CT and CPX (ratios of 0.48 and 0.50 ) but only CPX treatment produces apoptosis. In CPX- resistant subclone WEHI-3B/CPXRES CT produces a down-modulation of Bcl-2 with a little increase of Bax expression (ratio 0.56 ) whereas CPX causes a dramatic down-regulation of Bax (ratio of 1.38).

\section{Discussion}

The heterogeneity in cell sensitivity to CT has been described as being dependent on cell membrane gangliosides with specific and functional competence and/or by different signal transduction mechanisms (mediated or not by cAMP accumulation) coupled or not with cell growth and proliferation. In WEHI-3B cells, the most important functional receptor for $\mathrm{CT}$ is Gal-GalNacGM1b ganglioside [28] and the inhibition of cell growth by CT seems mainly related to intracellular cAMP accumulation induced by CT binding to Gal-GalNacGM1b [15] rather than by CT binding to GM1a. Our previous study showed that WEHI3B/CTRES cells, lacking in Gal-GalNacGM1b, did not accumulate cAMP after CT treatment [17]. The present study shows that in the sensitive WEHI-3B cells, following CT treatment, a dramatic sequence of effects (inhibition of clonogenicity and proliferation and increasing of PDT, PKA activity and apoptosis) occurs whereas none of these events are observed in the resistant subclone WEHI3B/CTRES (Figure 1, 2, 5). In many other models it has been reported that cAMP accumulation can accelerate the apoptotic programme acting on cellular cAMP dependent protein-kinases as PKA, MAP-K, ROCK, RSK and also on extracellular kinases (ERK1-2) [29-33]. Also the effects observed in CT-treated WEHI-3B cells appear triggered by cAMP accumulation because CT stimulation produces a significant (six-fold) increase of PKA activity that, in turn, could affect the cell cycle, resulting in a longer PDT and an anticlonogenic/antiproliferative effect. In WEHI3B/CTRES, cAMP accumulation is almost absent and a very poor activation of PKA is seen without increase of PDT and no inhibition of growth. The low activity of H-89 in inhibiting CT-dependent PKA activation could explain

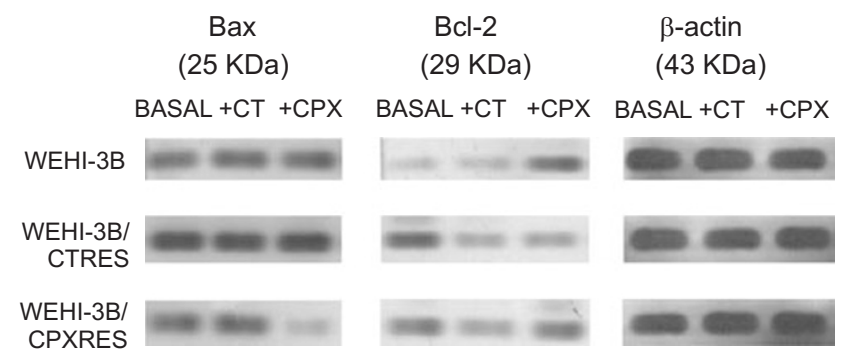

Figure 6 Expression of Bax and Bcl-2 proteins in WEHI-3B, WEHI3B/CTRES and WEHI-3B/CPXRES cell lines. The expression of Bax $(25 \mathrm{kDa})$ and $\mathrm{Bcl}-2(29 \mathrm{kDa})$ proteins has been evaluated on basal conditions and after treatment of cells with CT. $\beta$-actin (43 $\mathrm{kDa}$ ) expresses the amount of proteins run in each lane. As described in the Material and Methods to evaluate the modulation of protein expression the two cell lines were also treated with a topoisomerase inhibitor (CPX). 
because $\mathrm{H}-89$ did not protect the cells from antiproliferative effect of CT. While it is surprising that H-89 stimulates the basal activity of PKA in both the two cell lines (Figure 3) probably because, in our experiments, the PKA activation assay was performed in the absence of exogenous cAMP. H-89 is known to inhibit both mitogen and stress activated kinases (but not structural ribosomal kinases) by targeting the ATP-binding site of a kinase [34, 35]. Therefore, this molecule could act as a competitive "agonist" of cAMP for the PKA or compete with ATP on the PKA binding site. The presence of $\mathrm{H}-89$ during the cell treatment could contribute to accumulation of intracellular ATP available in the phosphorylation step of the in vitro assay. In any case, our data confirm the doubts that have been expressed also by other authors on the specificity of this molecule and suggest the need for caution in using $\mathrm{H}-89$ in models in which different kinases systems can be involved [36].

Our observations on apoptosis and Bcl-2 and Bax expression (Figures 4-6) show that, in parental CT sensitive WEHI-3B cells, anti-apoptotic Bcl-2 protein is not modulated by CT treatment whereas is dramatically upregulated by CPX. This suggests that these cells are able to up-regulate $\mathrm{Bcl}-2$ to oppose apoptosis but (as expected) at very high drug concentrations the mechanism fails to protect the cells (Bcl-2/Bax ratio being about 0.9). In WEHI-3B/CPXRES cells (resistant to CPX), the treatment with CPX does not modulate the expression of Bcl-2 but produces a down-modulation of Bax giving a reason of the resistance of these cells to CPX-induced apoptosis because the $\mathrm{Bcl}-2 / \mathrm{Bax}$ ratio is increased to values of about 1.4. This mechanism does not work by treating cells with CT that, on the contrary, produces a down regulation of Bcl-2 and a little increase of Bax allowing the cells to proceed into apoptosis. It remains more difficult to understand the behavior of WEHI-3B/CTRES in which Bax expression was not modulated and Bcl-2 was down-regulated by both $\mathrm{CT}$ and CPX. In spite of the down-modulation of Bcl-2 by CT, these cells are protected from CT- induced apoptosis (with a Bcl-2/Bax ratio of about 0.5 ). The above observations do not prove the role of $\mathrm{Bcl}-2$ expression in the mechanism of resistance to CT-induced apoptosis of WEHI-3B/CTRES, but clearly demonstrate that CT modulates Bcl-2 expression in the absence of cAMP accumulation [17]. As some authors have reported that down-regulation of Bcl-2 level by $\mathrm{CT}$ would be mediated by PKA and cAMP accumulation [37], our results suggest to discuss the matter on the possible relations between PKA, cAMP and Bcl-2 because in our cells the down-modulation of Bcl-2 follows other signal pathways. In general we think that cAMP, PKA and $\mathrm{Bcl}-2$ relations need to be more studied because there are many contradictory data in literature as that reported for S-49 cells in which Bcl-2 over-expression prevents apoptosis [38] but does not block the cAMP mediated $\mathrm{G}_{1}$ growth arrest [39], blocks efficiently 8-Cl-cAMP-induced apoptosis but does not abrogate the 8-Cl-cAMP-induced inhibition of cell proliferation [40]. As suggested by many authors [41-43], it is probable that Bcl-2 has variable and distinct biological functions (such as different compoundspecificity both on apoptosis and on cell cycle) that need to be better defined. In this panorama, the homogeneity of our cell model (one sensitive parental strain and two derived clones with different uncrossed specific resistance to $\mathrm{CT}$ and CPX) provides a new and interesting tool for better investigating the relationship between the $\mathrm{CT}$ signal transduction mechanisms and $\mathrm{Bcl}-2$ expression and function.

\section{References}

1 Fishman P. Role of membrane gangliosides in the binding and action of bacterial toxins. J Membr Biol 1982; 69:85-97.

2 Griffiths SL, Finkelstein RA, Critchley DR. Characterization of the receptor for cholera toxin and Escherichia coli heat-labile toxin in rabbit intestinal brush borders. Biochem J 1986; 238:313322.

3 Holmgren J, Lindblad H, Fredman P, Svennerholm L, Myrvold A. Comparison of receptors for cholera and Escherichia coli enterotoxins in human intestine. Gastroenterology 1985; 89:2735 .

4 Nakamura K, Suzuki M, Inagaki F, Yamakawa T, Suzuki A. A new ganglioside showing cholera genoid-binding activity in mouse spleen. J Biochem 1987; 101:825-835.

5 Pacuszka T, Bradley RM, Fishman PH. Neoglycolipid analogues of ganglioside GM1 as functional receptors of cholera toxin. Biochemistry 1991; 30:2563-2570.

6 Smets LA, Van Roy H. Mitogenic and anti-mitogenic effect of cholera toxin-mediated cyclic AMP levels in 3T3 cells. J Cell Physiol 1987; 133:395-399.

7 Rozengurt E, Legg A, Strang G, Courtenay-Luck N. Cyclic AMP: a mitogenic signal for Swiss 3 T3 cells. Proc Natl Acad Sci U S A 1981; 78:4392-4396.

8 Enomoto K, Gill DM. Cholera toxin activation of adenylatecyclase. Biol Chem 1980; 255:1252-1258.

9 Anderson DL, Tsoukas CD. Cholera toxin inhibits resting human $\mathrm{T}$ cell activation via a cAMP-independent pathway. J Immunol 1989; 43:3642-3647.

10 Chang FH, Bourne HR. Cholera toxin induces cAMP-independent degradation of Gs. J Biol Chem 1989; 264:5352-5357.

11 Francis ML, Okazaki I, Moss J, et al. cAMP-independent effects of cholera toxin on B cell activation. J Immunol 1995; 154:49564964.

12 Gouy H, Cefai D, Christensen SB, Debre P, Bismuth G. Cyclic AMP and inositol phosphate-independent inhibition of $\mathrm{Ca} 2+$ influx by cholera toxin in CD3-stimulated Jurkat T cells. J Immunol 1991; 147:757-7566.

13 Viallet J, Sharoni Y, Fricht H, et al. EA. Cholera toxin inhibits signal transduction by several mitogens and the in vitro growth of human small cells lung cancer. J Clin Invest 1990; 86:19041912.

14 Pessina A, Mineo E, Masserini M, Neri MG, Cocuzza CE. Inhibi- 
tion of murine leukemia (WEHI-3B and L1210) proliferation by cholera toxin B subunit. Biochem Biophys Acta 1989; 1013:206211.

15 Giuliani A, Calappi E, Mineo E, et al. The different inhibiting effect of Cholera toxin on two leukemia cell lines does not correlate with their toxin binding capacity. Mol Cell Biochem 1995; 152:103-112.

16 Pessina A, Mineo E, Neri MG, et al. SR-4987 and L1210 cell lines two models in which Cholera Toxin susceptibility does not correlate with cAMP accumulation and ganglioside content. Cell Mol Biol 1998; 44:933-940.

17 Pessina A, Giuliani A, Croera C, et al. Selection of a WEHI-3B leukaemia cell subclone resistant to inhibition by cholera toxin. Mol Cell Biochem 2002; 2333:19-26.

18 Warner LN, Moore MAS, Metcalf D. A transplantable myelomonocytic leukemia in Balb/c mice: cytology, kariotipe and muramidase content. J Natl Cancer Inst 1969; 43:963-982.

19 Pessina A, Mineo E, Gribaldo L, et al. Susceptibility of leukemia cell lines to quinolones and induction of resistance to ciprofloxacin in WEHI-3B $\left(\mathrm{D}^{+}\right)$leukaemia cells. Cancer J 1993; 6:291-297.

20 Pessina A, Gribaldo L, Mineo E, Neri MG. In vitro short-term and long-term cytotoxicity of fluoroquinolones on murine cell lines. Ind J Exp Biol 1994; 32:113-118.

21 McAteer JA, Devis J. Basic cell culture tecnique and the maintenance of cell lines. In: Davis JM, editor. Basic Cell Culture. Ed. Oxford University Press, Oxford. 1994; 93-148.

22 Donta ST. Comparison of the effects of cholera enterotoxin and ACTH on adrenal cells in tissue culture. Am J Phisiol 1974; 27:109-113.

23 Mossman T. Rapid colorimetric assay for cellular growth and survival: Application to proliferation and cytotoxicity assays. J Immunol Meth 1983; 65:55-63.

24 Hermann M, Lorenz HM, Voll R, et al. A rapid and simple method for the isolation of apoptotic DNA fragments. Nucl Acids Res 1994; $22: 5506$.

25 Bradford MM. A rapid and sensitive method for the quantitation of microgram quantities of protein utilizing the principle of protein-dye binding. Anal Biochem 1976; 72:248-254.

26 Laemli UK. Cleavage of structural proteins during the assembly of the head of bacteriophage T4. Nature 1970; 227:680-685.

27 Towbin H, Staehelin T, Gordon J. Electrophoretic transfer of proteins from polyacrylamide gels to nitrocellulose sheets: procedure and some applications. Biotechnology 1979; 24:145-149.

28 Yohe HC, Macala LJ, Giordano G, McHurray WJ. GM1b and GM1b-GalNAc: Major gangliosides of murine-derived macrophage-like WEHI-3 cells. Biochem Biophys Acta 1992; 1109:210-217.

29 Matuszyk J, Cebrat M, Kalas W, Strzadala L. HA1004, an inhibitor of serine/threonine protein kinase, restores the sensitivity of thymic lymphomas to $\mathrm{Ca}^{2+}$-mediated apoptosis through a protein kinase A-independent mechanism. Int Immunopharmacol 2002; 2:435-442.
30 Zhu Q, Zhang JW, Zhu HQ, et al. Synergic effects of arsenic trioxide and cAMP during acute promyeloytic leukemia cell maturation subtends a novel signalling cross-talk. Blood 2002; 99:1014-1022.

31 Muthing J, Schwinzer B, Peter-Katalinic J, Egge H, Mühlradt PF. Gangliosides of murine T lymphocyte subpopulations. Biochemistry 1989; 28:2923-2929.

32 Cook SJ, McCormick F. Inhibition by cAMP of Ras-dependent activation of Raf. Science 1993; 262:1069-1072.

33 McKenzie FR, Pouyssegur J. cAMP-mediated growth inhibition in fibroblasts is not mediated via mitogen-activated protein (MAP) kinase (ERK) inhibition. cAMP-dependent protein kinase induces a temporal shift in growth factor-stimulated MAP kinases. J Biol Chem 1996; 271:13476-13483.

34 Thomson S, Clayton AL, Hazzalin CA, et al. The nucleosomal response associated with immediate-early gene induction is mediated via alternative MAP kinase cascades: MSK1 as a potential histone H3/HMG-14 kinase. Embo J 1999; 18:4779-4793.

35 Chijiwa T, Mishima A, Hagiwara M, et al. Inhibition of forskolininduced neurite outgrowth and protein phosphorylation by a newly synthesized selective inhibitor of cyclic AMP-dependent protein kinase, $\mathrm{N}$-[2-(p-bromocinnamylamino)ethyl]-5-isoquinolinesulfonamide (H-89), of PC12D pheochromocytoma cells. J Biol Chem 1990; 265:5267-5272.

36 Leemhuis J, Boutillier S, Schmidt G, Meyer DK. The protein kinase A inhibitor H-89 acts on cell morphology by inhibiting Rho kinase. J Pharmacol Exp Ther 2002; 300:1000-1007.

37 Itano Y, Ito A, Uehara T, Nomura Y. Regulation of Bcl-2 protein expression in human neuroblastoma SH-SY5Y cells: positive and negative effects of protein kinases $\mathrm{C}$ and $\mathrm{A}$, respectably. $\mathrm{J}$ Neurochem 1996; 67:131-137.

38 Yan L, Herrmann V, Hofer JK, Insel PA. beta-adrenergic receptor/cAMP-mediated signaling and apoptosis of S49 lymphoma cells. Am J Physiol Cell Physiol 2000; 279:C1665-1674.

39 Zhang L, Insel PA. Bcl-2 protects lymphoma cells from apoptosis but not growth arrest promoted by cAMP and dexamethasone. Am J Physiol Cell Physiol 2001; 281:C1642-1647.

40 Kim SN, Kim SG, Park JH, et al. Dual anticancer activity of 8-Cl-cAMP: inhibition of cell proliferation and induction of apoptotic cell death. Biochem Biophys Res Commun 2000; 273:404-410.

41 Belka C, Budach W. Anti-apoptotic Bcl-2 proteins: structure, function and relevance for radiation biology. Int J Radiat Biol 2002; 78:643-658.

42 Del Bufalo D, Biroccio A, Trisciuoglio D, et al. Bcl-2 has differing effects on the sensitivity of breast cancer cells depending on the antineoplastic drug used. Eur J Cancer 2002; 38:2455-262.

43 Furukawa Y, Iwase S, Kikuchi J, et al. Phosphorylation of Bcl-2 protein by CDC2 kinase during G2/M phases and its role in cell cycle regulation. J Biol Chem 2000; 275:21661-21667.

Edited by Zhong Cheng Zheng 